\title{
HUMAN IMPACT ON HUNGARIAN KARST TERRAINS, WITH SPECIAL REGARD TO SYLVICULTURE
}

\author{
VPLIV ČLOVEKA NA KRAS, S POUDARKOM NA \\ IZKORIŠČANJU GOZDA NA MAD•ARSKEM
}

ILONA BÁRÁNY-KEVEI ${ }^{1}$

${ }^{1}$ University of Szeged, Department of Climatology and Landscape Ecology, 6722, Szeged,Egyetem u.2. Hungary, e-mail:keveibar@earth.geo.u-szeged.hu 


\section{Summary}

UDC: 551.44:504.03:630(439)

\section{Ilona Bárány-Kevei: Human impact on karst terrains, with special regard to sylviculture in Hungary}

This study represents the changes of Hungarian karst terrains due to human impacts paying special attention to sylviculture. The functioning of the karst geo-ecosystem is considerably determined by the climate-soilvegetation system, which will influence the dynamism of karst development. Most of the Hungarian karst terrains are the scene of sylviculture. The planting of non-adequate forest associations resulted the alteration of climate and soils, which resulted in a change of the intensity of karst corrosion. This paper focuses on the change of sylviculture in the Aggtelek National Park, a World Heritage site, and makes suggestions for optimal land use.

Key words: karst landscape changes, human impact on karst, sylviculture on karst.

\section{Izvleček}

UDK: 551.44:504.03:630(439)

\section{Ilona Bárány-Kevei: Vpliv človeka na kras, s poudarkom na izkoriščanju gozda na Mad•arskem}

V sestavku so predstavljene spremembe, nastale na mad•arskem krasu kot posledica človekove dejavnosti, posebno izkoriščanja gozda. Delovanje geo-ekosistema na krasu je v veliki meri odvisno od odnosov podnebje - prst - rastje, kar vpliva na hitrost razvoja krasa. Večina krasa na Mad•arskem je vključenega v gospodarjenje z gozdovi. Sajenje neustreznih gozdnih sestojev ima lahko kot posledico spreminjanje klime in prsti, kar vodi k spremembam intenzivnosti korozije. Prispevek obravnava spremembe gospodarjenja z gozdom v narodnem parku Aggtelek, ki je na seznamu svetovne naravne dediščine, in predlaga ustreznejšo rabo tal. Ključne besede: sprememba kraškega površja, vpliv človeka na kras, gozdarjenje na krasu, Aggtelek, Mad•arska. 


\section{INTRODUCTION}

The karst regions of Hungary are situated in the Transdanubian and Northern Mountain Ranges (Fig.1). Only smaller patches of isolated karsts are found in the southern parts of the Transdanubian Mountains. $1.5 \%$ of the area of Hungary, in regions of Triassic limestones and dolomites, is affected by karstification. Parts of the Bakony, Vértes, Buda and the Mecsek andVillányi Mountains are nature conservation areas. The karst regions of Aggtelek and Bükk Mountains are National Parks.

Tectonic movements have been intensive in the Transdanubian Mountains, forming a series of horsts and grabens. In Northern Hungary, less faulted and characteristic karst features also developed, the karsts of the Mecsek Mountains and Villány Hills being of the same type as the karst of Aggtelek and Bükk. Intensive karstification has occurred on several occasions in different geological periods. Thus, both fossil and recent karst features occur on Hungarian karsts.

During the latest phase of karstification, landscape transformation in the karst environment started with the appearance of early humans. In the Middle and Upper Pleistocene prehistoric man used caves in Hungary. Early man gathered firewood from the karsts, thus the deforestation of karst regions began. Later human activity modified karst formation by agriculture on the one hand and by industry on the other. Agricultural activity was intensive in Aggtelek and Villány Mountains at the turn of the century. For this reason soil erosion was so widespread that rock solution decreased. At the same time the microclimate and vegetation were also modified. With industrialisation and the beginning of mining, the undesired ground waters were pumped out. Consequently, karstic aquifer levels sank in the Transdanubian Mountain Range.

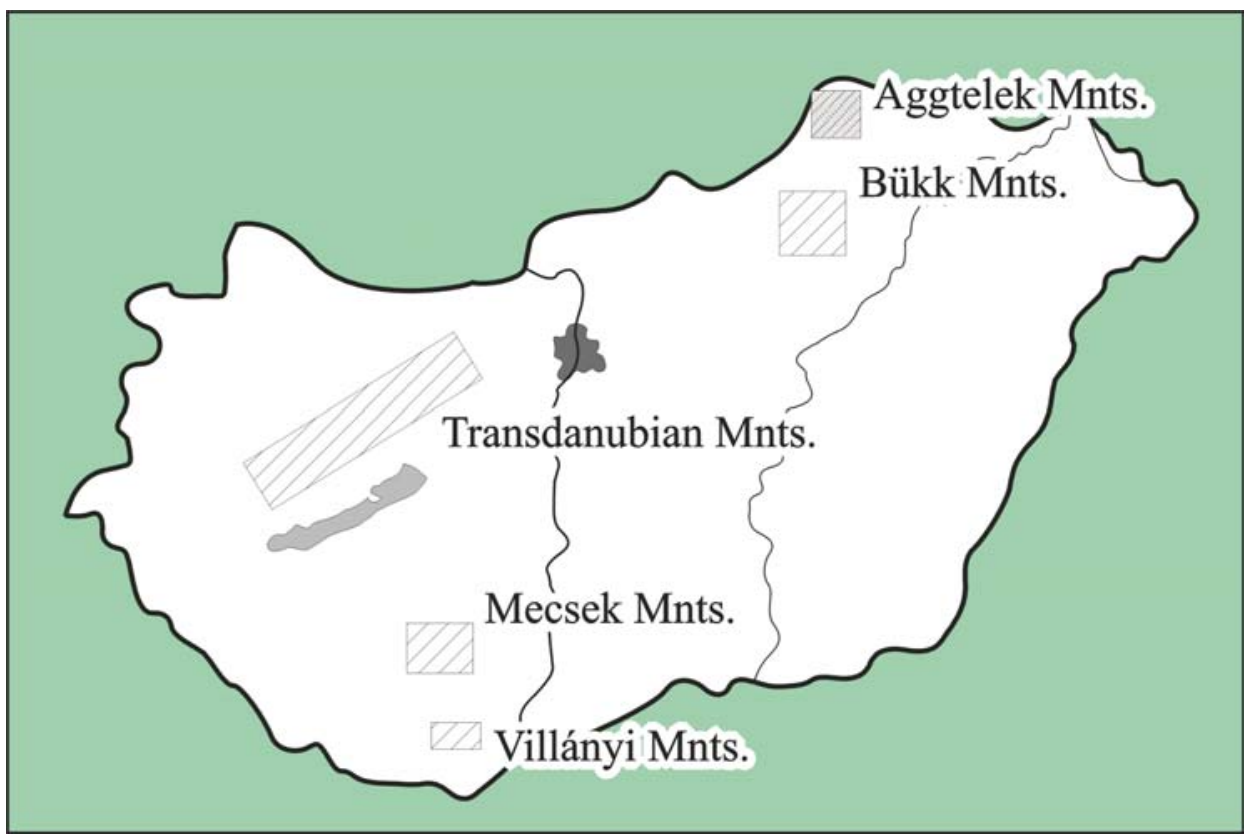

Fig. 1: Location of the Hungarian karsts. 


\section{PROBLEM}

Karst terrains have been cultivated in Hungary for hundreds of years. The impact of cultivation can be followed in the development of the surface and subsurface karst formations.

The karstic terrains of Hungary can be found in mountaneous and hilly areas; therefore, their usability has strong connections to sylviculture.

Before the time when the largest clearances occurred, the ecological balance soon recovered after natural disasters. Nowadays, when human activity significantly changes the impacts of the environment from different directions, the sustainable sylviculture, as woodland cultivation, consciously preserves the natural conditions of an area.

In some of my previous studies, I have already introduced the model which summarises the connections of the karst ecological system (Kevei-Bárány 1998a, 1998b). Associated with this model, I study those factors and processes, which are relevant from the point of all the processes of the landscape changes in any karstic environment. The system of climate-soil-vegetation has crucial importance from point of view of karst dynamism. The changes of these factors influence the intensity and tendency of the landscape change processes. This paper focuses on the change of sylviculture in the Aggtelek National Park, a World Heritage site, and gives suggestions for optimal sylviculture.

\section{METHODS}

The digital terrain model was created under ArcView using 1:10 000 scale topographical maps, and it gave the basis of the altitude, exposure and slope angle values. The forest plots are the smallest planning units in practice, which could be displayed as polygons with certain data in dBASE format: forest climate, genetic and physical soil type, depth of soil. The resulted values were classified and encoded. The place values of the codes gave the value of different characteristics therefore, all of them could be described by numbers. The sum of these numbers on a given point reflects the characteristics of the habitat and the related association. The map of result was created by overlaying, and the qualification of a certain site could be given in any resolution.

\section{DISCUSSION}

Ten years after the establishment of the Aggtelek National Park in 1985, its caves and caverns were declared to be the part of the World Heritage in 1995. This means that the protection of the area was further enhanced. The retaining of the subsurface geomorphological forms requires strict protection at any rate; therefore, the utilisation of the surface areas is regulated. As the major part of the Aggtelek karst terrains is open karst, covered with soils the use of both the immediate karst surface and the adjoining non-karst terrain influence the condition of the karst-system. $77 \%$ of the National Park is covered with forests, so this branch of agriculture operates also in accordance with the rules of the sustainable sylviculture.

The mosaic quality of the landscape structure was formed by the natural land use. In this type of land use the earlier dominance of sylviculture, based on small communities, was replaced by grassing and tilling arable land on the less good karst soils. Until the establishing of the National Park, forests were felled for timber at high rates later they were geminated. On the clearings grassland was developed; and, therefore, hay production dominated. 
Where the forest clearance was followed by the reafforestation of the former natural or quasinatural grasslands or by forest renewal the biodiversity of the given karst area is reduced (Table 1.).

Table 1. Biodiversity of the different species, in the Aggtelek area

\begin{tabular}{cccccc} 
Deciduous-forest & $\begin{array}{c}\text { Species } \\
\text { of trees }\end{array}$ & $\begin{array}{c}\text { Species } \\
\text { graminaceous }\end{array}$ & Pine-forest & $\begin{array}{c}\text { Species } \\
\text { trees }\end{array}$ & $\begin{array}{c}\text { Species } \\
\text { graminaceous }\end{array}$ \\
\hline $\begin{array}{c}\text { Beech forest with } \\
\text { hornbeam }\end{array}$ & 16 & $\mathbf{8 4}$ & Pinus nigra forest & 1 & $\mathbf{1 9}$ \\
\hline $\begin{array}{c}\text { Oak forest with } \\
\text { hornbeam }\end{array}$ & 18 & $\mathbf{1 3 3}$ & Picea excelsa forest & $1-2$ & $\mathbf{1 6}$ \\
\hline Turkey oak forest & 26 & $\mathbf{2 0 3}$ & Pinus silvestris forest & $1-3$ & $\mathbf{2 1}$ \\
\hline
\end{tabular}

The repeated forest clearances and the plantation of non-native species changed the ecological processes of the karst system. Especially the exotic pine forests altered the soils: they became more acidic; therefore the intensity of corrosion became different (Table.2).

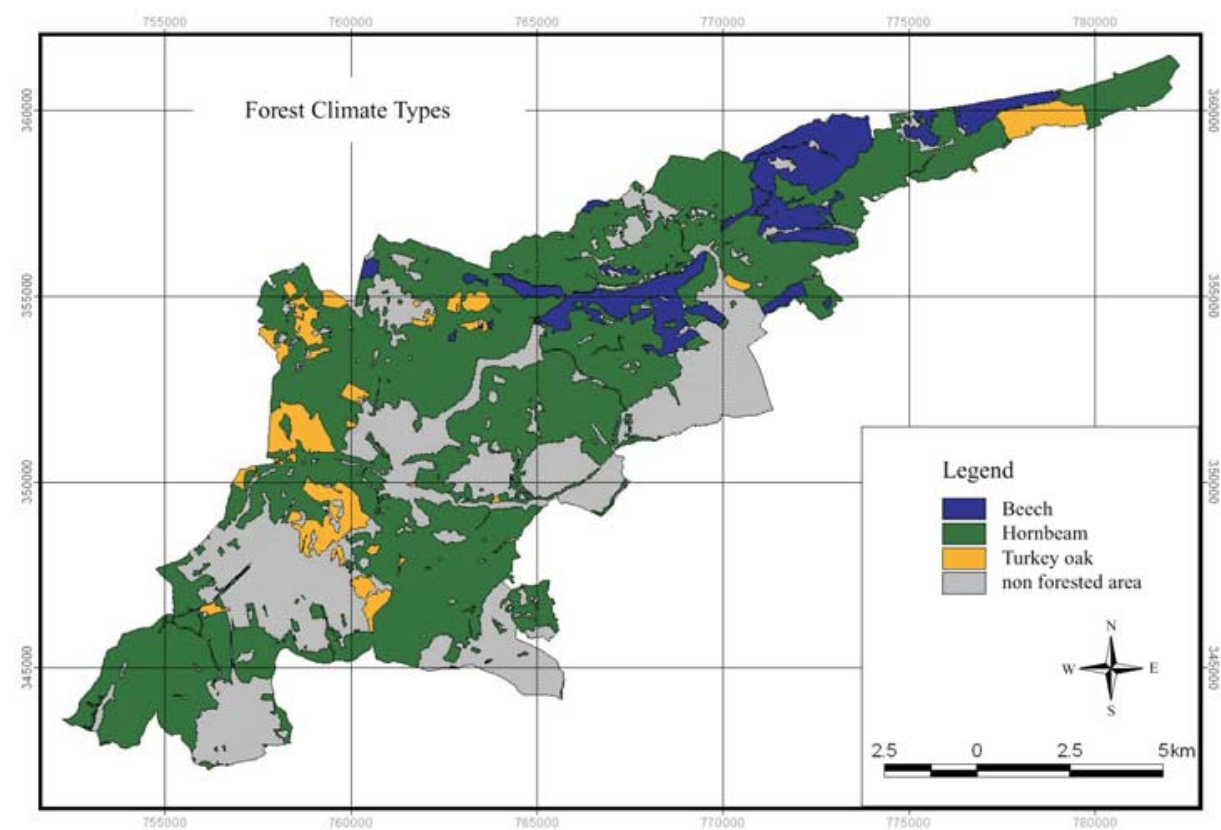

Fig. 2: Forest climate types in Aggtelek National Park. 


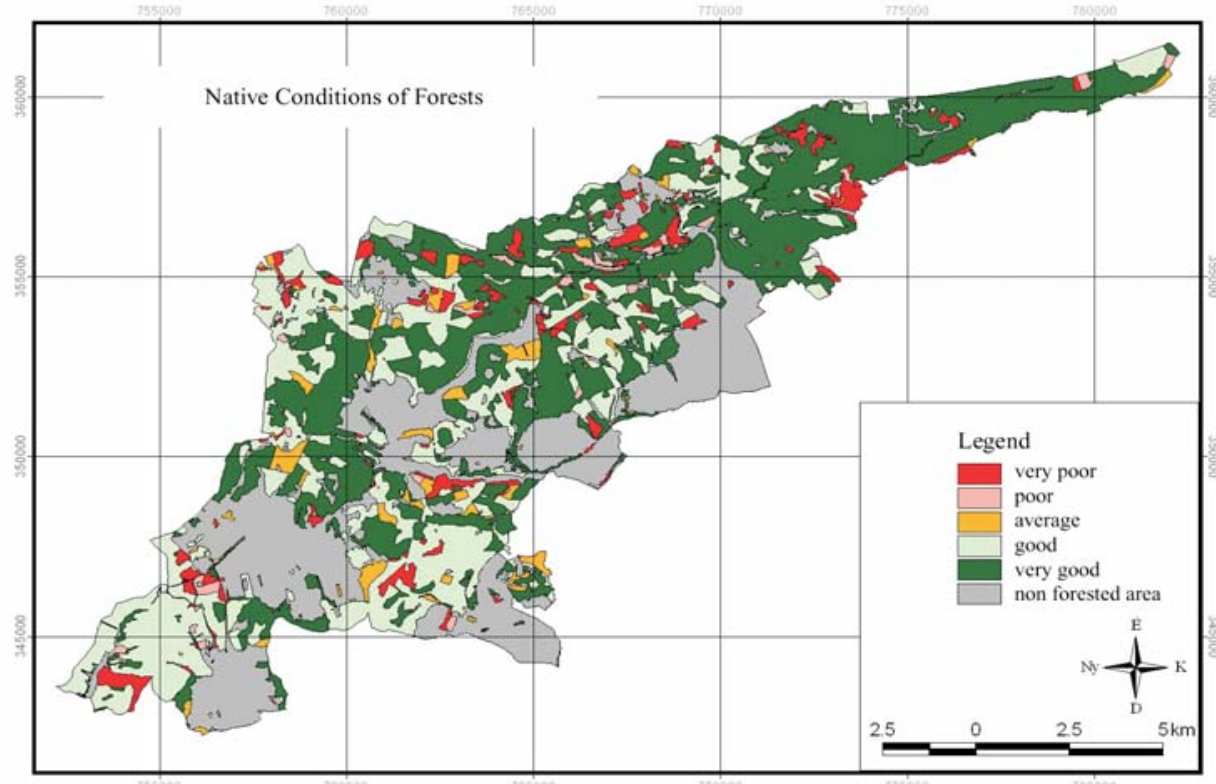

Fig. 3: Native condition offorests in Aggtelek National Park.

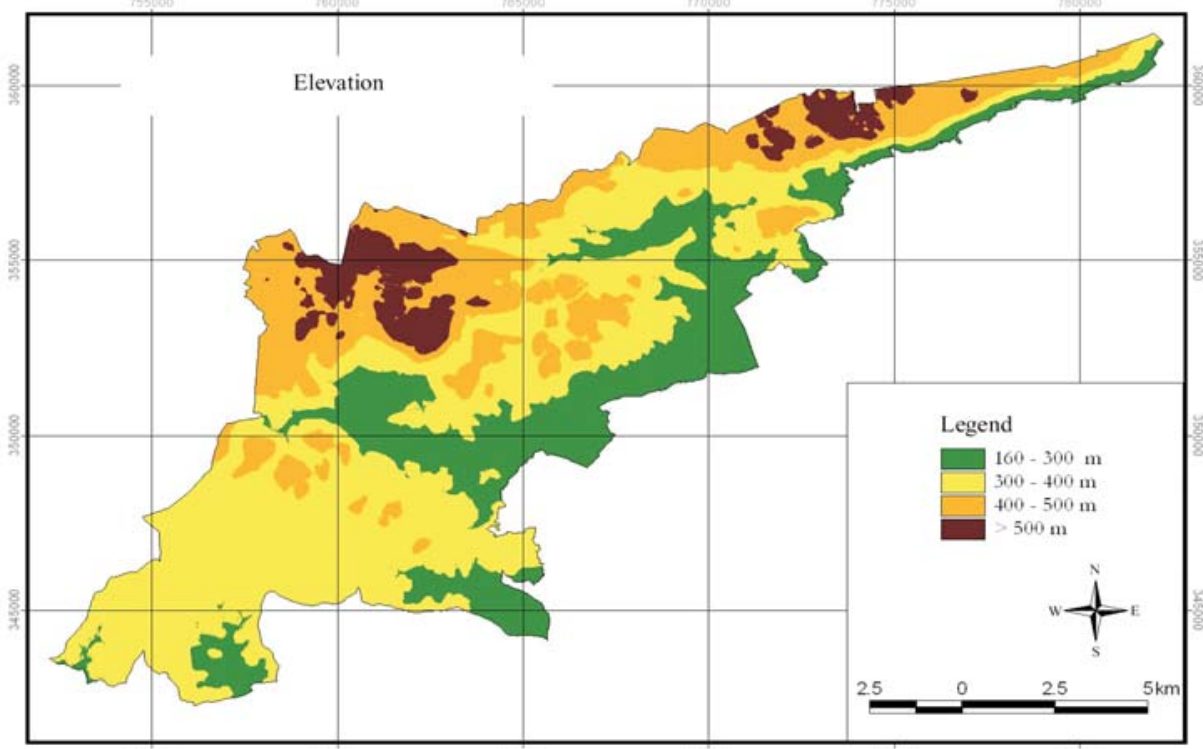

Fig. 4: Elevations in Aggtelek National Park. 


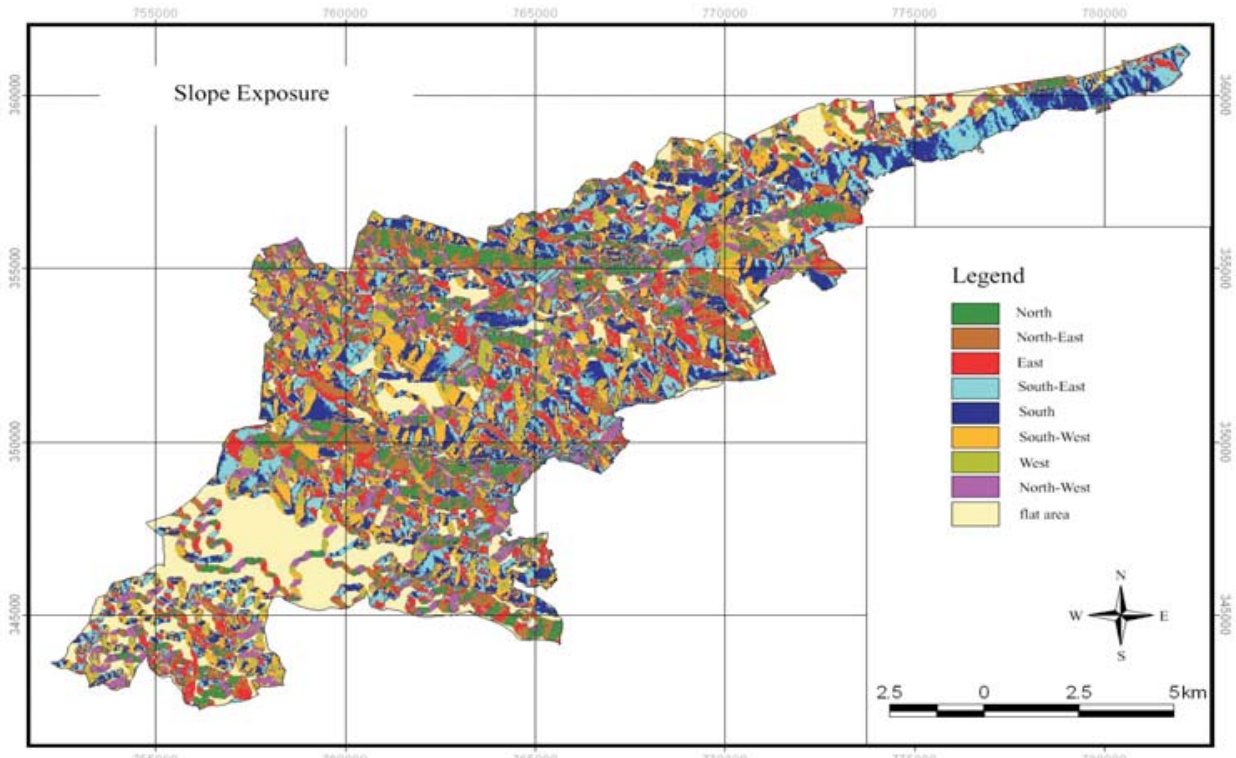

Fig. 5: Slope exposure in Aggtelek National Park.

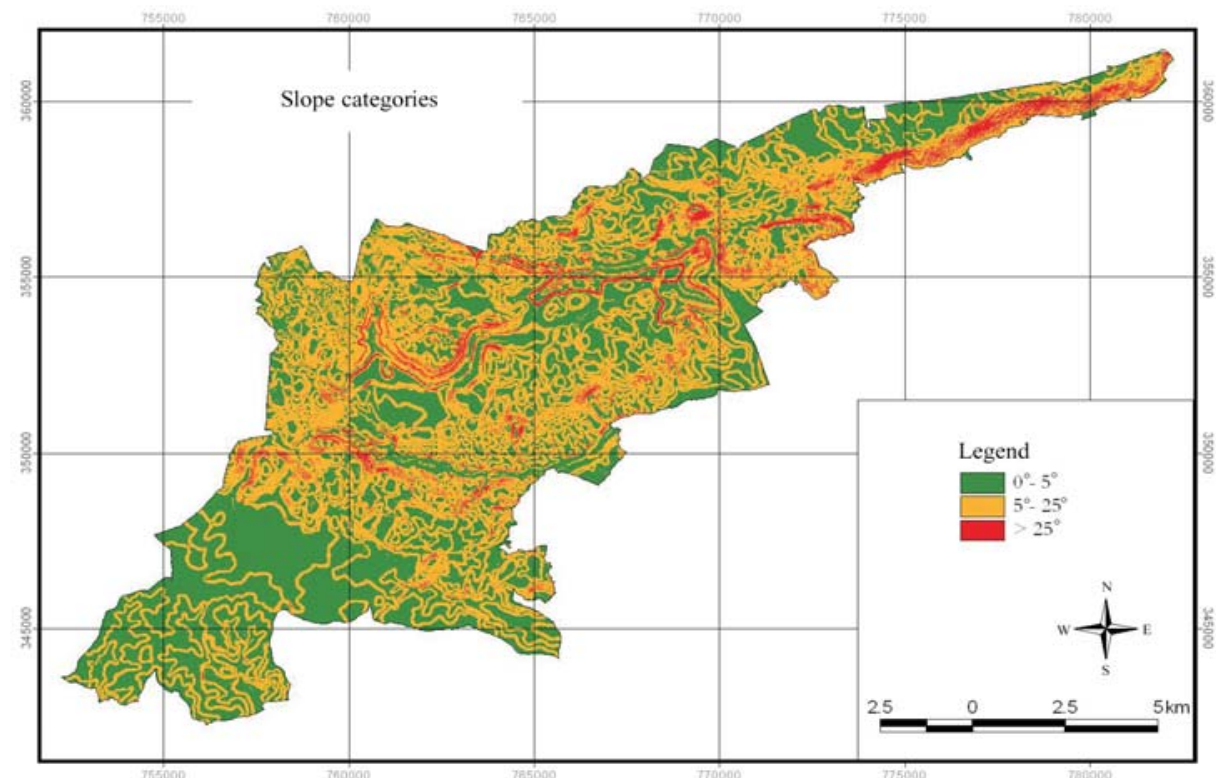

Fig.6: Slope categories in Aggtelek National Park. 


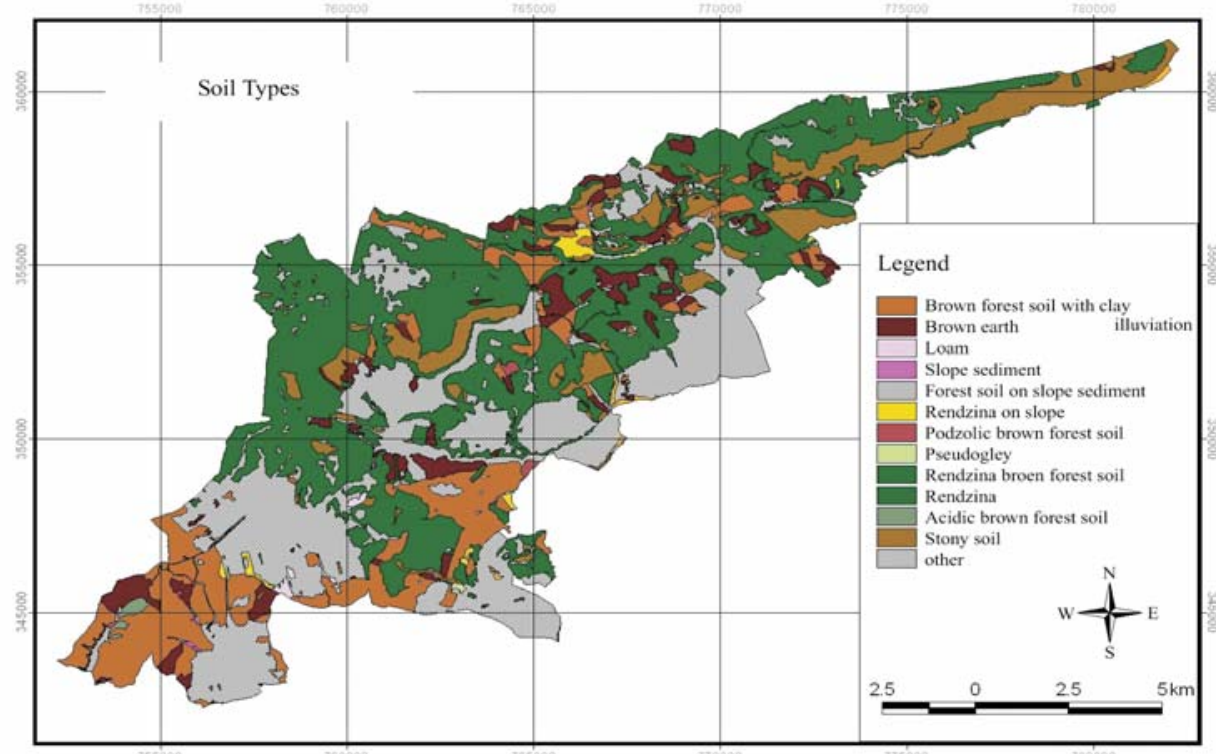

Fig. 7: Soil types in Aggtelek National Park.

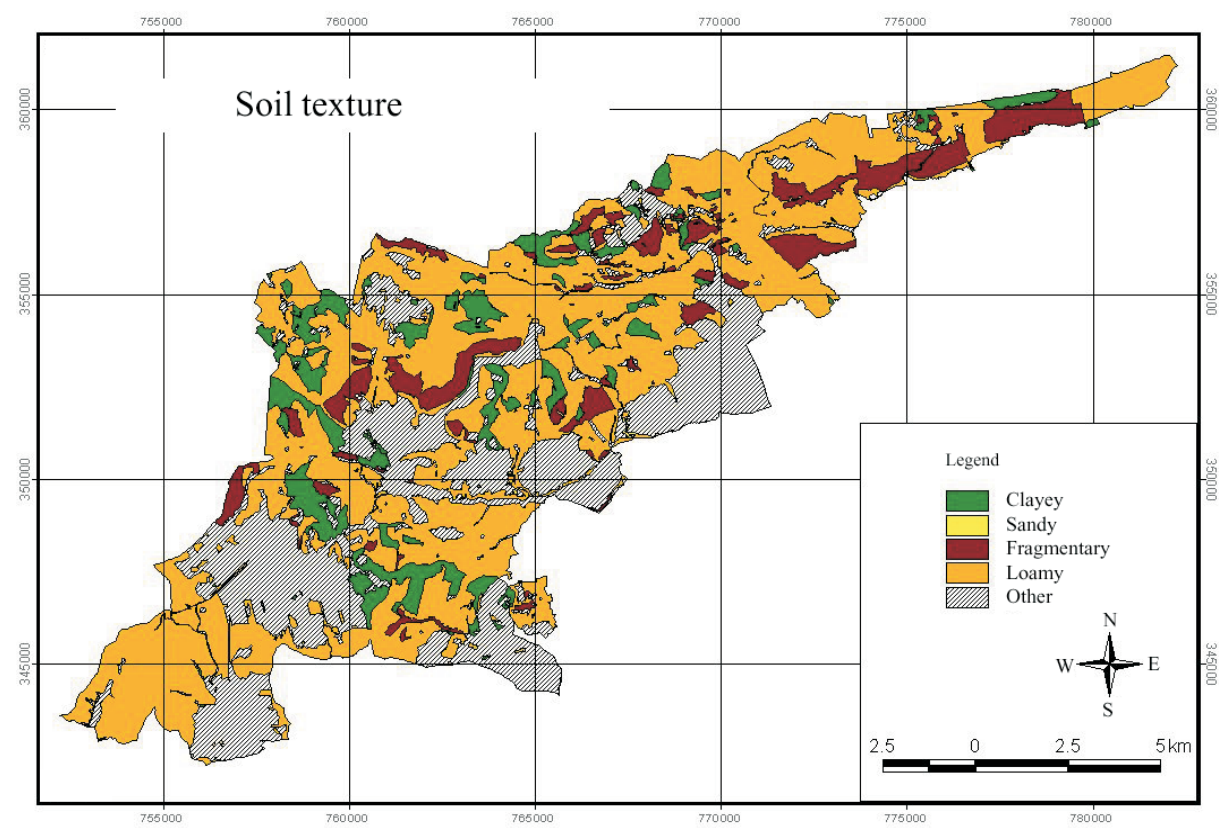

Fig. 8: Soil texture in Aggtelek National Park. 


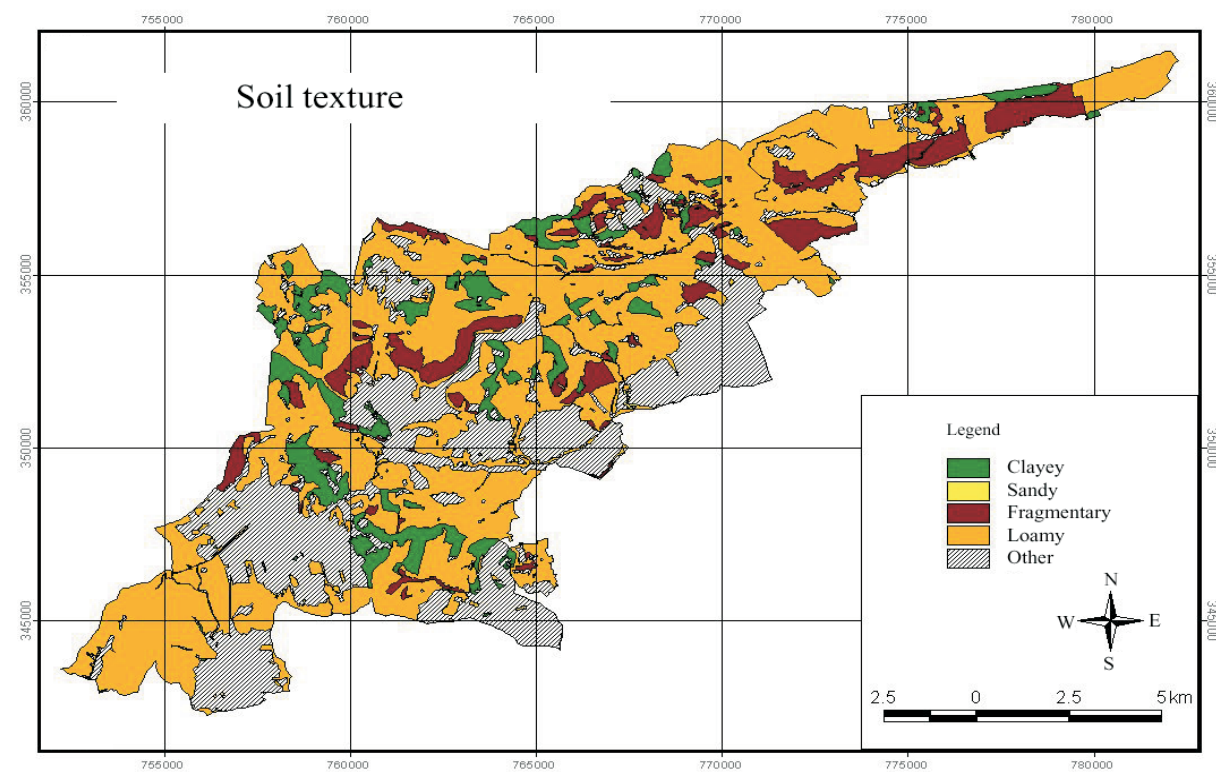

Fig. 9: Soil depth in Aggtelek National Park.

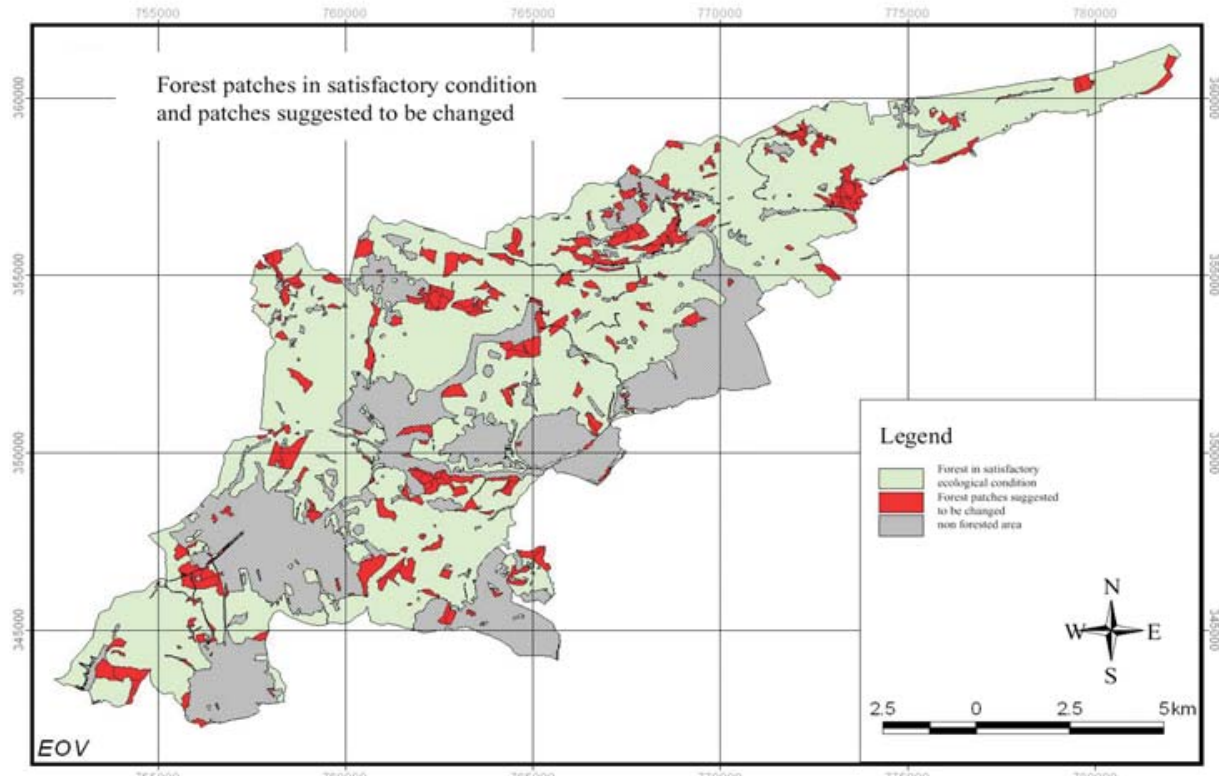

Fig. 10: Forest patches in satisfactory condition and patches suggested to be changed in Aggtelek National Park. 
Table 2. Grouping of the $\mathrm{pH}$ values of the soil samples in areas with different vegetation cover in the Aggtelek Karst in 1998 /No. of samples in percentage \%/ (Bárány-Kevei-Goldie - HoykZseni, 2000):

\begin{tabular}{lccccc} 
PH & Sum (\%) & Oak forest & Grassland & Pine forest & Arable land \\
\hline Strong acid $(<4,5)$ & $2(3,3 \%)$ & $2(2,57 \%)$ & 0 & 0 & 0 \\
\hline Acid $(4,5-5,5)$ & $\mathbf{2 6}(\mathbf{4 2 , 6} \%)$ & $\mathbf{2 0}(\mathbf{5 7 , 1} \%)$ & $2(11,1 \%)$ & $\mathbf{4 ( 1 0 0} \%)$ & 0 \\
\hline Weak acid $(5,5-6,8)$ & $16(26,2 \%)$ & $6(17,1 \%)$ & $\mathbf{1 0} \mathbf{( 5 5 , 6 \% )}$ & 0 & 0 \\
\hline Neutral $(6,8-7,2)$ & $7(11,5 \%)$ & $4(11,4 \%)$ & $3(16,7 \%)$ & 0 & 0 \\
\hline Weak neutral $(7,2-8,5)$ & $10(16,4 \%)$ & $3(8,6 \%)$ & $3(16,3 \% 9$ & 0 & $\mathbf{4 ( 1 0 0 ~ \% )}$ \\
\hline Summ 61 $(100 \%)$ & $35(100 \%)$ & $18(\%)$ & $4(100 \%)$ & $4(100 \%)$ & \\
\hline
\end{tabular}

\section{COMPUTER ASSISTED FOREST OPTIMIZATION}

Applying detailed forestry data we created a thematic map series: maps of forest climate (Fig.2 of forest (Fig.3.), maps of altitude (Fig.4.), exposure (Fig. 5), slope (Fig. 6.) and soil maps with genetic (Fig.7) and physical soil type (Fig.8) and depth of tilth (Fig. 9). Using the above mentioned maps we could relate potential wood association to each selected habitat under ArcView. The digital map of these potential forests is the basis of further calculations and measurements, as far as each forest plot has certain characteristics.

The resulting map was created by overlaying of above mentioned maps, and the qualification of a certain site could be given in any resolution (Fig.10).

The resulted map shows that on most of the territory it is not necessary to change the presentday woods. On the sites which are in a very poor, satisfactory or average conditions the woodtype should be changed according to their landscape-ecological values. Mostly new mixed beech forests, hornbeam-beech or hornbeam-oak woods should be planted. The resulting map shows all those places, where changes are necessary, but of course with field work the probable mistakes should be checked.

\section{CONCLUSION}

- Forestry had always played an important role on the functioning of karstecological system on the karst terrains, and probably it will in the future as well.

- The study represents the potential forest changes due to human impact on the example of Aggtelek National Park in Hungary.

- The computer-based analysis pointed on those sites, where the forest type should be changed to reconstruct natural conditions.

- Based on the ecological needs, we have determined those wood types which should be optimal on the given site.

- The method could be used on any other karst terrains, and in practice optimal land-use maps could be created in landscape planning. 


\section{REFERENCES}

Bárány-Kevei, I. (1998a): Geoecological system of karsts. Acta Carsologica. Krasoslovni Zbornik, XXVII/1. Ljubljana. pp. 13-25.

Bárány-Kevei, I (1998b).: The geo-ecology of three Hungarian karsts. Cave und Karst Science. Transaction of the British Cave Research Association. Vol. 25. Num. 3. December. 113117.

Botos, Cs. (1999): An ecologically based, computer assisted, forest rehabilitation project in the Aggtelek National Park, Hungary. . in.: Essays in the ecology and conservation of karst. (Ed.: Bárány-Kevei,I.-Gunn,J.) pp.47-53. 